\title{
The Remystification Of Women's Narratives in Sihir Perempuan And Gentayangan By Intan Paramaditha: A Magical Realism Study
}

\author{
Cahyaningrum Dewojati ${ }^{1}$, Rina Zuliana ${ }^{2}$ \\ \{cahyaningrum@ugm.ac.id\} \\ Literary Studies, Faculty of Cultural Sciences, Universitas Gadjah Mada \\ Sosiohumaniora Street, Bulaksumur, Yogyakarta 55281, Indonesia
}

\begin{abstract}
This paper aims to reveal the remystification of women's narratives in Sihir Perempuan and Gentayangan by Intan Paramaditha through the magical realism theory of Wendy B. Haris by using qualitative descriptive analysis method. As a postmodern fiction, Sihir Perempuan and Gentayangan narrate and restructure women's myths from the exclusion of the old hegemonistic and moralistic narratives. The remystification at the story is a woman's resistance against the shackles of monstering, vampirism, gendering horror, and so on, which is perceived as a sexual deviance and control. These feminine elements are presented in the 'real' and 'magical' landscapes. In the discourse, the meaning of magical realism within both works goes beyond the feminine elements in the story, which is the critique against ideology, social, and culture. The research results show that Intan Paramaditha's works play as a critique against the urban life stability which still situates women in dangerous stereotypes. Besides, they function as a local and global world portrayal, between 'modern' and 'postmodern', between 'power' and 'illness', and other matters regarding the 'real' and 'magical' images.
\end{abstract}

Keywords: The Remystification of Women's Narratives, Magical Realism, Modern Fiction, Intan Paramadhita

\section{Introduction}

Gender issues are as problematic as the narrative of magical realism, all of which are found in modern and postmodern discourse [1][2][3][4]. The characteristics of postmodernism that grow out of postmodernism in this issue results in the forms of dialogue, polyphonic, and centralist. This case is similar to how women's knowledge works. Thus, magical realism participates in the component of woman's postmodernism. Glucksmann [5] mentions that in the process of writing, feminine metaphors come up as in-pause elements with certain rationality discredited according to the idea of a historical and symbolic continuum.

Thus, a new heterogeneity and distinction come over. The narrative mode of magical realism belongs to a certain sense in finding female spirits characterized by diffusion structures, polyvocality, and attention to embodiment issues; to the earth-centered spirit world, and to the collectivity, which is active in magical realism in general scope, regardless of authorship. Intan Paramadita, in her works, refigure various female characters in tales, mysteries, and horrors written around the 2000s with a time setting around it. In Sihir Perempuan[6] and Gentayangan 
[7], Intan Paramaditha processed stories into horror genres, myths, and old stories within a feminist perspective. The depiction of a female character in the evolving narratives places women, besides marginalized figures, as a horror and mysterious figures.

In the Indonesian cinema, for example, women are often represented as spirits and ghosts who rise back from their previous dark past, whether as victims of rape, suicide, or other tragedies that evoke the horror and magical narrative of women. Fantasy stories developed in European mythology put women as bad looking witches. Unlike shamans or black magicians in Indonesia, shamans or black magicians in the growing mythology are portrayed as bad looking creatures with some lingering internal organs. Bubandt [8] states that ghost narratives are created to perpetuate power.

However, unlike the western ghosts who are present because of emotional struggles, Indonesian ghosts are born from the collective trauma of society, for example the legend of Sundel Bolong was born from rape victims, while the myth about Wewe Gombel was brought up because of the disappearance of a small child. Magical realism is a new genre that emerged since the mid-twentieth century, in 1955 to be precise, as an alternative genre to the previously hegemonic literary genre. Browers [9] states that magical realism is a genre or literary understanding that is quite popular and has even entered many creative industries such as film, fine arts, design, photography, and so on. Faris [10] states that magical realism is a work that combines two contradictory ways of understanding life, namely what is called realistic code and magic code, in a balanced position in the sense that they do not nullify one another.

In the previous research, Muhtarom [11] reviewed three short stories by Gabriel Garcia Marquez, Triyanto Triwikromo, and AS. Like through a magical realism approach. The magical realism in the three prose writers provides a capacity for meaning that goes beyond the realist. Marquez's short stories represent the magical world of children that cannot be found in the adult world. Triyanto Triwikromo's work brings together the understanding of magical realism with spirituality. Meanwhile, in AS Laksana's work, the form of magical realism is packed with modes of exchange and transfer of "self" to the experiences of characters who transcend realist boundaries.

Research on the works of Intan Paramadhita have been done, especially those related to the feminine elements of the story. The discussion still tends to revolve around the problem of women figure in the space of daily life as marginalized, stereotyped, and number-two figure. This research aims to find out the complexity of Intan Paramaditha's works, primarily about the realist and magical territorial within the units of her stories.

\section{Research Methods}

The research method or method of obtaining knowledge must be in accordance with the fact that the object under study exists, in accordance with what is called the nature of the object's existence. Knowledge that conforms to reality is considered true knowledge. The fact that the object exists is expressed by the concepts, theories and definitions contained in the hypothesis and the variables determined on its basis [12].

The research methodology is based on a conceptual framework using a qualitative descriptive approach. In answering the question of magical realism in Intan Paramaditha's work, this study employs three works of Intan Paramaditha: Sihir Perempuan and Gentayangan the primary data. The secondary data sources are writings, essays, articles, and journals related to magical realism and narratives about women. Data collection is done by doing heuristic and 
hermeneutic readings to collect words, sentences, paragraphs, and other linguistic units that show narratives in the concept of magical realism.

Further, the researcher groups and classifies them based on irreducible element descriptions, phenomenal worlds, unsettling doubt, merging realms, and disruption of time, space, and identity to discover the levels of magical realism, the form of narrative remystification in real and magical landscapes, along with the social, cultural, and ideological contexts to criticize. The data analysis method is based on how magical realism theory works by analyzing lingual units in the data from the main source with data taken from the supporting sources. So, it can draw a connection between elements of magical realism and narrative remystification in the works of Intan Paramaditha in building magical realism literary works.

\section{Results and Discussion}

\subsection{Sihir Perempuan and Gentayangan: Women in Real and Magical Landscapes}

The narrative of women in general brings myths that marginalize women's positions. Intan Paramaditha's works present new myths of women against the old narratives. These myths are presented through framed tales, horrors, and mystery stories that tell women between 'real' and 'magical' landscapes. The level of magical realism in the works of Intan Paramaditha will be identified through five elements: irreducible element, phenomenal world, unsettling doubt, merging realms, and disruption of time, space, and identity.

\section{Irreducible Element}

Irreducible elements cannot be explained through the universal law based on logical and general knowledge, or inherited beliefs. In the genre of magical realism, the reader is faced with questions that are quite complicated regarding the status of the events and the character of the story. Voice of narratives is not easily accepted by sensory senses, so it displays something magical and surpasses the concept of uncanny. In this concept, the stories are articulated in not detailed form or fully integrated with the reality written.

Sihir perempuan states the same thing, which places the figures of female horror stories in scary and mysterious tales. In "Pemintal Kegelapan", how horror and mystery cling to the daily lives of characters. The mother character who has been a protector has come up as a fearsome figure. The woman called Mother is portrayed as a female ghost character who is on the attic above her house. In the morning she incarnates into a whole woman, and at night turns into a creepy figure.

In creepy character description, it is between being just an 'imaginative' life or being in the construction of the character "I" imaginative mind, or indeed happening in the real life. Such supernatural experiences are difficult to distinguish because they are in two opposite boundaries of space, between magical and real life, between rational and irrational which are blended into one frame of a story. Magical life can be presented through the medium of language, as Rushdie and Wajsbrot [13] state:

"You must use language in a manner which permits God to exist - the divine to be as real as the divan I am sitting on "can no longer express or account for the absurd reality of the world we live in - a world which has the capability of destroying itself at any moment."

This combination of Godliness and absurdity for Faris [10] characterizes magical realism when it tries to bridge the gap between the ancient Magism and modern absurdity, which often 
includes atrocities which are scientifically invented. Magical realism creates a narrative space between the two.

In the short story of "Vampires", the depiction of the character goes far beyond the legend of 'vampires' as a popular mythological figure since the 18th century spread across Europe. The role of vampires as the life eater (bloodsuckers) in the European version of narrative tradition has been reduced to a bloodsucker in the life of romance between men and women. The rebuilding of the vampire narrative to show that the allegory of 'vampire' is meant to illustrate the problems in the phenomenon of postmodernism. Intan Paramaditha's "Vampire" character is attached to a male character who leaves the family to find a new partner and roam at night to find female as their victim.

"laki-laki itu tahu kau tinggal sendirian. Kau dan aku memang makhluk-makhluk kesepian. Aku si pengisap kehidupan yang sekarat karena merah sudah nyaris habis punah berhenti titik. [6].... Dipucuk es krim ada ceri bulat mengilat. Buah menggoda, menantang bahaya. Akankah aku jatuh? Tapi aku begitu menginginkannya. Aku si pengisap penyedot kehidupan. Lehernya begitu indah. Dan aku begitu haus Darah [6]"

"The man knows you live alone. You and I are lonely creatures. I'm a dying life sucker because the red is almost extinct; it stops at a point. [6] .... At the top of the ice cream, there are shiny round cherries, seductive fruits defying danger. Will I fall? But I really wanted it. I'm a life sucker. Her neck is so beautiful. And I'm so thirsty of Blood [6]”

Intan Paramaditha's storytelling technique barely leaves any boundary lines between the real and the magical space. Both elements are blended into the real life of the character in living daily activities and problems. Perempuan Buta Tanpa Ibu Jari is a short story that adopts the story of Cinderella presented from the point of view of Cinderlela's older sister who is renarrated by naming the character as Sinderlarat. This short story is devoted to re-initiation of the narrative of female beauty in the context of postmodernism.

The discourse of beauty myths described with small feet is illustrated by how Sinderlarat's two half-siblings cut off their heels and toes to be proposed and taken to castle by the Prince. Her two older siblings were sad along the way and were eventually dumped for their own lies. Elements of tales like this are asmilated by Intan in magical and realist form. On the other hand, such stories cannot be well reduced by the author. Surely, the 'magical' presence in Sinderalat's fairy tale is a satire of the postmodern conditions that still place women in male domination.

Faris [10] mentions feminine elements in magical realism, such as the housekeeping role, the identity of the "virgin paper" attached to the female, and cooking activities are the myths rejected by female authors. Bringing women to life in magical realism narratives can harm or interfere the stability of power. The myths and narratives of perempuan dalam rumah were built to undermine the power women could actually dominate in spaces that have long been dominated by patriarchal culture.

"Pak Sopir menginjak gas agar taksinya melaju lebih kencang hingga kau merasa mual. Kalau ia menyetir seperti ini terus bisa-bisa kau berakhir di neraka. Ia berusaha menyalip mobil di depannya, sebuah Jaguar tahun 70-an bercat hijau pudar dan penuh dempul. Kaca mobil bagian belakang ditempeli stiker bertuliskan Good girls go to heaven, bad girls go everywhere. Saat melewati mobil itu, si sopir sempat mengintip kea rah pengemudi, seorang perempuan lanjut usia dengan rambut keriting berkibar. 
“Hah, nenek-nenek," ia menghela nafas panjang, antara kesal dan maklum.” Semoga dia masuk surge" [6].

"The driver stepped on the gas, so the taxi went faster until you felt nauseous. If he keeps driving such way, you might end up in hell. He was trying to overtake the car in front of him, a Jaguar from the 70s painted faded green and covered in putty. The rear windshield is affixed with a sticker that reads 'Good girls go to heaven; bad girls go everywhere'. When passing over the car, the driver peeked at the driver, an elderly woman with curly fluttering hair. "Huh, a grandma," he sighed, between annoyed and symphatetic. "May he go into the heaven" [6].

From the entire works of Intan Paramaditha, the 'magical' elements are attached to female characters represented as ghostly, horror, mysterious, and scary. In Gentayangan, women are represented as ghosts who move from place to place. In male working areas, such as in taxi cars, slogans are affixed to create myths that women mentioned by Faris [10] are real. The slogan "'Good girls go to heaven, bad girls go everywhere" is a feminine element that is created by the male world. The creation of this myth is to discipline female position in order to avoid it to harm the position of male. Women's lives are similar to ghosts, dolls, or other mystical items that is intended to attach an identity to women figure.

\section{Phenomenal World}

Phenomenal world refers to the 'real' things in the narrative of the story. It describes about realities of magical realism. This element is a setting based on the real and chronological history. The urban settings and big cities are selected by Intan Paramaditha, from Jakarta to New York and Amsterdaam, from churches to mosques. Setting can also be identified through the activities attached to urban society. Gentayangan is set in many foreign countries, one of which is Amsterdam, so the description of the 'real' phenomenon is emphasized as the main background of the story. It spots as a 'real' hint in the magical realism.

Stasiun Amsterdam Centraal. Kau melangkah keluar dari kereta dan mengikuti orangorang yang berjejal turun melalui escalator. Sesampainya di bawah, kerumunan terpencar seperti semut, sedangkan kau diam melongo mengamati took di kanan-kiri sembari mencari meja informasi. Berbekal keterangan dari petugas, kau naik trem dari Central kea rah Niewmaarkt, tempatmu menetap hingga sebulan kemudian. Lewat iklan di internet, kau temukan apartemen dua kamar yang salah satunya disewakan untuk sementara waktu. Ini jelas lebih murah daripada tinggal di hotel [7].

Amsterdam Centraal Station. You stepped out of the train and followed the people crowding down through the escalator. Arriving at the ground, the crowd scattered like ants while you're still gawking, observing the stores in the right-left side while looking for the information desk. By the description of the station officer, you boarded the tram from Central to Niewmaarkt, where you lived until the next month. Through the advertisement on the internet, you found a two-bedroom apartment, one of which was rent for a while. This is obviously cheaper than a hotel [7].

Phenomenal world in Sihir Perempuan and Gentayangan includes the places, objects, and time. The character profession in the works of Intan Paramaditha also shows the elements that build magical realism. In the short story "Mobil Jenazah", Sihir Perempuan, the profession 
of the female character is a worker at a company. She works until night late. It is also found in other stories, showing the urban society activities from the early morning until they close back their eyes. These events still provide a place for the 'magical' beings to exist in the real world, so the levels between the real and the magical world can be impartial in the works of Intan Paramaditha.

\subsection{Unsettling Doubt}

The theory of unsettling doubt reveals disconcerting and unsolvable anxiety. In this state, doubts arise between two understandings that are contradictory over the events within. Doubts can also arise from cultural clashes between the events in the narrative and reality which traditionally exclude them. Faris [10] describes three forms of hesitation which is triggered by the text, object property, and cultural background of the reader.

Overall, the doubt which is most closely perceived by the reader is triggered by the text, which is at the relatively paradox description of the female characters. The readers are led into the complex condition of the female character. The complex illustrations actually represent various cultural backgrounds of women's construction in diverse regions. However, the setting taken by Intan is the crowded city whose residents must have certain standard horror stories. On her stories, she brings out a quite heterogeneous horror story.

Sihir Perempuan is a collection of short stories that heterogenize women's stereotypes. The works of Intan Paramaditha present the fairy tales of the Western genre and the local ghosts. The cultural background of the readers also effects on their doubt when reading the works of Intan Paramaditha. Her works are complex for taking various settings in Indonesia and abroad. Intan Paramaditha brings the heterogeneity of the discourse and myths of women, so the complexity effects on the reader's doubt mainly because of socio-cultural issues.

\section{Merging Realms}

Merging realms in the works Intan Paramaditha fuses the construction or discourse of women in the 'real' and 'magical' landscape. Faris [10] defines this category as a merger between the magical (with regard to traditional beliefs) and the real (modern) world. The boundary merging between the magical and the real world is not visible. As in the "Pemintal Kegelapan", the mother has two different inherent characters. The 'real' character of mother with her 'magical' mother plays as the attic ghost of the darkness spinner. The merging lets the short story attached with the concept of magical realism genre.

Kutajamkan penglihatanku. Kubawa ingatanku pada masa-masa kami masih menikmati misteri loteng itu, mengucapkan selamat dating pada imajinasi liar tanpa batas dan malam-malam meringkuk di balik selimut. Tiba-tiba kusadari aku tengah merinding. Aku memang melihat Ibu. Ya, perempuan itu. Rambutnya terurai, wajahnya penuh guratan pedih, matanya nyalang seperti bola api yang menari-nari melumatkan siapa pun yang menatap. Hantu perempuan yang memendam cinta, rindu, sakit, nafsu, amarah-memintal gairah pekat tanpa henti, tanpa selesai [6].

I sharpen my vision. I brought my memory back at times we enjoyed the attic mystery, welcoming the limitless wild imagination, and the nights snuggled under the blanket. I suddenly realised I was in the middle of creeps. I did see the mother. Yes, the woman. Her hair was loose, her face was full of painful scars, her eyes glared like a dancing 
fire ball pulverizing anyone who stared at. A female ghost who hid love, longing, pain, lust, burning anger, which is continuously spinning desire, unstopped [6].

Sihir Perempuan and Gentayangan presents a quite complex description of merging realms because it consists of various stories and point of views. It is also found in the short story "Vampir" which presents the construction a man who has a magical side, but he is not considered scary or creepy. The characteristics of the merging realms in the works of Intan position the scary and creepy women on the one hand. On the other hand, a woman is a realistic character with her femininity sides. It is a merging process between the real and magical world.

In the short story "Loteng Rumah", the setting is not only constructed as a living room and rest. In the magical world, attic is a place where the haunting ghost gather. It is also associated with mysteries of a child since he was a kid, so it creates a construct that the attic, which is quiet, is a "spinner of darkness". Darkness deals with glooms in a magical world, but in the reality, a dark room does not mean gloom or creep, but there are factors that cause the room dark. Because it does not bring any effect, no one handles it. In Sihir Perempuan, the attic is transformed into two worlds which includes a mystical and realist region.

\section{Disruption of Time, Space, and Identity}

Disruption of time, space, and identity means time, space, and identity switches [10]. The evidence of the time disruption (time interference or disruption) in the works of Intan Paramaditha is the time for the coming of the ghosts blended with the real life. The blending has not limited that the horror, creepy, haunting, and scary do not only come at night but in the morning or the afternoon.

In Gentayangan, the ghost can roam and go around without thinking of the time that is sacred. This happens because it has been blended with the real life, so the ghost does not only mean scary, but this identity is pinned on women who like to roam. The word 'haunt' has been equated with the word 'roam'. The new space, time, and identity is more likely real because it involves on a new space, time, and identity.

The narratives constructed by Intan Paramaditha overall help women create a new identity. The complexity presented by a Intan is no longer on women's issues in the local landscape, but she describes about the urban society who can turn into anything and anyone. The heterogeneity presented by Intan Paramaditha regarding women has its own identity, but this is the characteristic of the gender narratives in magical realism, that the author tries to show a fresh identity on the characters formulated.

\subsection{Socio-cultural Context}

Socio-cultural background created by Intan Paramadhita is the narratives of women within urban culture. The culture of the urban society has been supported with the advanced development of times compared to the rural areas which still maintain local culture. Thus, their cultural is naturally heterogeneous, referring to not only a particular point of view. Two different cultural codes are presented in the perfect update by Intan Paramaditha. Women who roam at night late with their night life is basically a habit. However, the construct of the old culture still haunts the girls because the old narratives are still maintained by men. The construction of the ghosts is also associated with women to castrate their existence and provide a stereotype that women are creepy, scary, horror, and mysterious.

The literary works of Intan Paramaditha function as a criticism against the stability of urban life that still position women in the disadvantaged stereotype. Magical realism in the works of 
Intan Paramaditha is a depiction of the local and the global world, between the 'modern' and 'postmodern', between 'power' and 'illness', and things associated with the 'real' and 'magical' realm.

\section{Conclusion}

The literary works of Intan Paramaditha are proses with magical realism genre by narrating the women's mystic story back from the old narrative, in either fairy tales, horror, or mystical. The feminism elements in the magical realism, such as the role of housekeeping, the identity of "virgin paper" attached to the women's body, and the cooking activity are the myths opposed by Intan Paramaditha.

She criticizes the construction of the ghost attached as the identity of women, the times considered sacred for women, and the spaces that should not be entered by women. Magical realism in the works of Intan Paramaditha then brings the new narrative of mystic that breaks all forms of time, space, and identity sacredness.

\section{References}

[1] Jardine, Alice, Gynesis: Configurations of Woman and Modernity, Itacha: Cornell University Press, 1985.

[2] Showalter, Elaine, "Feminist Criticism in the Wilderness" dalam Critical Inquiry: Special Issue: Writing and Sexual Diference 8, pp. 179-205, 1981.

[3] Lifton, Robert J, "Woman as Knower" dalam History and Human Survival, New York: Random House, pp. 270-72, 1970.

[4] Robertson, Mary, "Hystery, Herstory, History: 'Imagining the Real' in Thomas's The White Hotel' Contamporary Literary 25, 4, pp. 466, 1984.

[5] Glucksmann, Christine Buci, Baroque Reason: The Aesthetics of Modernity, trans Patrick Camiller, London: Sage, 1994.

[6] Paramadhita, Intan, Sihir Perempuan, second edition, Jakarta: Gramedia Pustaka Utama, 2017

[7] Paramadhita, Intan, Gentayangan, Jakarta: Gramedia Pustaka Utama, 2017.

[8] Bubandt, Nils, "A Psychology of Ghosts: The Regime of The Self and the Reinvention of Spirit in Indonesia and Beyond", A Journal of Social Antrphology and Comparative Sociology, pp. 1-23, 2012.

[9] Browers, Maggie Ann.. Magical Realism, London and New York: Routledge, 2004.

[10] Faris, Wendy B, 2004, Ordinary Enchantmens: Magical Realism and Remistifications of Narratives. Nashville: Vanderbilt University Press, 2004.

[11] Muhtarom, "Realisme Magis dalam Cerpen: Kasus Cerpen Gabriel Garcia Marquez, Triyanto Triwikromo, dan A.S. Laksana", Poetika Journal, 2 (2), pp. 148-157, $2014 .$.

[12] Faruk, Metode Penelitian Sastra, Yogyakarta: Pustaka Pelajar, 2012

[13] Rushdie, Salman, dan Cécile Wajsbrot, "Utiliser une technique qui permette à Dieu d'exister," Quinzaine Littéraire 449, pp. 22, 1985. 